\title{
Manifestations of Toxic Masculinity in Cormac McCarthy's Blood Meridian or the Evening Redness in the West
}

\section{Vahit Yasayan \\ Erzurum Technical University}

\begin{abstract}
This article analyzes Blood Meridian or The Evening Redness in the West (1985) - the first product of Cormac McCarthy's borderlands immersion-by deploying the concept of "toxic masculinity," an exaggerated masculinity related mythically to the role of the cowboy/warrior/pioneer, which creates recklessness and eventually perpetuates violence. In other words, it explores how perfunctorily embracing, or endeavoring to fulfill, hegemonic masculine ideals bring about self-destructive behaviors in McCarthy's monolithically male characters on the Texas-Mexico border in the 1850s. Even though the term "toxic masculinity" was seldomly used in the 1980s when McCarthy wrote this novel, he clearly anticipates and historicizes the evolution of American masculinity as embodied by the cowboy/warrior/pioneer into a form of toxic masculinity. By doing so, he presages the gradual cultural recognition that such masculinity is not the generic standard against which all versions of gendered identity should be measured but is in fact toxic, pathological, political, and problematic. By exposing toxic cowboy mythology and deploying it to construct alternative masculinities, McCarthy questions the Frontier Thesis and Manifest Destiny while disrupting the toxic assumptions about manhood and masculine identities they were intended to uphold. The new vision McCarthy presents in Blood Meridian challenges the development of American national identity based on the vicious conquest of impoverished, discriminated, oppressed, and racialized Others and exploited, feminized nature.
\end{abstract}

Keywords: Toxic Masculinity, Cormac McCarthy, Masculinity Studies, Western, Blood Meridian 
Even though there are many masculinities - that is, there are many ways to identify as a male in society - a significant construction of masculinity in the United States involves the "projection of toughness and aggression and the rejection of traits and behaviors associated with femininity, such as expressing feelings" (Humphris 1). In other words, what has come to be called "toxic masculinity." In the 1980s, Shepherd Bliss coined the word "toxic masculinity" to illustrate a kind of dangerous, hegemonic masculinity that intimidates life, health, and safety through destructive practices and behavior. Similarly, psychologist Terry A. Kupers uses toxic masculinity to mean "the constellation of socially regressive male traits that serve to foster domination, the devaluation of women, homophobia, and wanton violence" (715). These characteristics contribute to a myriad of public health issues such as assaults perpetrated by men, alcoholism, depression, suicide, and resistance to mental health interventions in the United States.

Another definition of toxic masculinity comes from James Messerschmidt's Hegemonic Masculinities and Camouflaged Politics (2010). In this work, he explores R.W. Connell's hegemonic masculinity as a theoretical concept and its consequences in American culture and society. In Masculinities (2005), Connell defines hegemonic masculinity as a kind of masculinity that a culture favors above all others, one that "subliminally" defines "what is normal for males in that culture, and imposes that definition of normality upon" other kinds of masculinities (76). In other words, Connell deals with the toxic practices that have originated out of what she calls as hegemonic masculinity. Its fundamental function is to authorize not only the dominant position of men, but also the dominance of particular social groups of men, along with their power, values, wealth and beliefs. Hegemonic masculinity has been subject to many criticisms because it oversimplifies power and dominance as a representation of reality rather than a perceived experience; it ignores women as a relevant contribution to hegemonic masculinity, and it ignores the number of men who hold great power in the United States but do not embody ideal masculinity. Messerschmidt reformulates hegemonic masculinity and develops a novel conceptualization of various masculinities. Specifically, Messerschmidt differentiates global, local, regional, transnational as well as toxic masculinities. Furthermore, he articulates a "dynamic of domination and subordination between hegemonic masculinity and toxic masculinities" (Messerschmidt 79). He comes to the conclusion that toxic masculinity is very much rooted in notions of rugged individualism, the nuclear family and expectations of 
men as providers in an increasingly adverse environment. In other words, he elucidates that cowboy masculinity is toxic in its roots and reinforces awful interactions between men and women in American society today. $\mathrm{He}$ acknowledges that American culture of toxic masculinity "turns boys into men who are unfeeling, robotic and totally lacking in coping mechanism" (82).

The difference between hegemonic masculinity and toxic masculinity is also voiced by Terry A. Kupers. Similar to hegemonic masculinity, toxic masculinity is featured by the coercion of rigorous gender roles, but also involves the "need to aggressively compete [with others] and dominate others" (715). According to Kupers, toxic masculinity concerned with hegemonic and hypermasculine behaviors and their socially, physically, and psychologically harmful effects on society, others, and oneself. As he states,

the term toxic masculinity is useful in discussions about gender and forms of masculinity because it delineates those aspects of hegemonic masculinity that are socially destructive, such as misogyny, homophobia, greed, and violent domination; and those that are culturally accepted and valued. After all, there is nothing especially toxic in a man's pride in his ability to win at sports, to maintain solidarity with a friend, to succeed at work, or to provide for his family. These positive pursuits are aspects of hegemonic masculinity, too, but they are hardly toxic. The subordinated masculinities that Connell contrasts with the hegemonic, and the profeminist alternative masculinities celebrated in the profeminist and antihomophobic men's movement, are examples of nontoxic aspects of expressed masculinities. (716)

According to Kupers, "toxic masculinity has four major components: suppression of anything stereotypically feminine; suppression of emotions related to vulnerability, like fear, sadness, or helplessness; male domination over women and other men; and aggression" (717). As he explicates, while all masculinities are not completely toxic,

there are many which contain toxic ideologies and traits. A structure is defined as toxic when it promotes negative outcomes, and toxic masculinity certainly achieves this; in particular, it displays its toxicity in the attitudes it promotes about what it means to perform masculinity and in the ways it objectifies and depersonalizes women. (718)

The term toxic masculinity is convenient in discussions about the history of gender and masculinity in the United States because it differentiates those aspects of hegemonic masculinity that are socially detrimental from those 
that are culturally accepted and valued. As a form of American masculinity, it does not demonize manliness or male attributes. Instead, it highlights the dreadful impact of adjusting to traditional traits such as competition, selfreliance, dominance and violent rapaciousness. Thus, as Olivia Campbell points out in The Cut, an objective of Masculinity Studies is to decode how toxic masculinity is indoctrinated as a "performative mask rather than a biological imperative." In other words, the field aims to address its roots, i.e., cowboy/warrior/pioneer masculinity.

Similar to Messerschmidt, Hugh Campbell also claims that toxic masculinity originated with white frontiersmen: it is "in considerable measure; constructed out of rural masculinity. The 'real man' of many currently hegemonic forms of masculinity is . . rural man" (20). In the United States, to many white, middle-class, Christian and heterosexual men, the cowboy figure has become "the image of a quintessential man" (19). As Donald Meisenheimer points out, "static both personally and racially, cowboy masculinity thus embodies impulses that are, at base, anti-revolutionary. Obviously, a deep-seated contradiction exists in genre-or gender-which promises 'new consciousness' and universal transformation through a totalizing stasis" (446). Similarly, in The Man They Wanted Me to Be: Toxic Masculinity and a Crisis of Our Own Making (2019) Jared Yates Sexton elucidates that

with the Industrial Revolution, and a shift from agrarian culture to mechanization, the promise of self-made fortune was realized by giants like John D. Rockefeller, Cornelius Vanderbilt, Andrew Carnegie, and men like them who built the country as we know it and, in doing so, employed generations of men who worked in miserable conditions for subpar pay. American masculinity and patriarchal society have roots that go back well past this time period. In fact, white American men have enjoyed privileges since before there was an America, and those privileges resulted in the overthrow of Native Americans, the enslavement of African Americans, mistreatment of minorities, the controlled subservience of women, and an order of hegemonic and toxic power that has existed well into the twenty-first century. It has defined the struggle of America since its conception. (10)

As Sexton points out, American masculinity has particularly potent and toxic system of power which has suppressed and otherized women and minorities for generations through systematic and methodized actions that were hegemonized by misogyny, sexism, racism, and "a unique brand of maleness that held sway over the United States of America since before its founding" (20). Thus, toxic masculinity derives from the myth of Manifest 
Destiny, which has vested within it an almighty responsibility to confiscate all of the frontier. It nostalgically celebrates and rationalizes Manifest Destiny and the so-called "winning of the west" in terms that are similar to those expressed in Frederick Jackson Turner's 1893 Frontier Thesis. According to Turner's seminal work The Frontier in American History (1921), the frontier "signified advancing waves of conflict across a wide and ever moving geographic plain where the social Darwinist contest between EuroAmerican and Indigenous cultures took place, at the same time demarcating the boundaries for the symbolic meeting place between savagery and civilization" (78). As Kupers argues, in the same way, Manifest Destiny promotes an

androcentric code of violence and racial purity on the erstwhile palimpsest of the West. For men interested in capitalizing on their white patriarchal privilege, a willingness to wage violence on anyone not white and male has developed in the West as the definition of toxic masculinity the cowboy oversees as a self-proclaimed suzerain. (713)

Thus, cowboy masculinity is a toxic, monolithic power structure held by men that dominates the lives of all who do not have access to privilege and protection. In many ways, "being a tough and rugged man" i.e., acting out according to codes of toxic masculinity - has outcomes for individual men and for society as a whole. As Howard Cunnell explicates in his article in The Guardian, many American men are raised to believe in toxic masculinity; yet, they cannot access the rewards it seemingly promotes. Therefore, they are "angry, depressed, violent and destructive." They are doomed to fail since they live "without encountering alternative narratives." Likewise, Jordan Stephens argues that "this toxic notion of masculinity is being championed by men who are so terrified of confronting any trauma experienced as children that they choose to project that torture on to the lives of others rather than themselves." Instead, they should be aware of how constructions of toxic masculinity produce harmful effects for themselves and for their environment, and strive to construct alternative masculinities.

This article explores Cormac McCarthy's Blood Meridian or The Evening Redness in the West (1985) - the first product of his borderlands immersion - within the framework of "toxic masculinity," an extreme hegemonic masculinity related mythically to the role of the cowboy/warrior/ pioneer, which creates recklessness and eventually perpetuates violence. In other words, this article explores how perfunctorily embracing, or endeavoring to fulfill, toxic masculine ideals brings about self-destructive behav- 
iors in McCarthy's monolithically male characters on the Texas-Mexico border in the 1850s. Even though the term toxic masculinity was seldomly used in the 1980s when McCarthy wrote this novel, he clearly anticipates and historicizes the evolution of American masculinity as embodied by the cowboy/warrior/pioneer into a form of toxic masculinity. ${ }^{1}$ By doing so, he presages the gradual cultural recognition that such masculinity is not the generic standard against which all versions of gendered identity should be measured but is, in fact toxic, pathological, political, and problematic. As a concept, toxic masculinity first originated on the American frontier as "rugged individualism," and was embodied by American cowboys. Eventually, it turned into the image of authentic "all-American" masculinity, which is a target of criticism within Masculinity Studies. Thus, McCarthy's Blood Meridian anticipates current discussions of "toxic masculinity" by indicating the overall influence of rigid patriarchal constructions on American manhood and the ways in which toxic masculinity transfers violence across generations of American men. These toxic behaviors do not bring the kid, McCarthy's protagonist, the sense of manhood he is looking for. As a matter of fact, just the opposite. As a cowboy, he heroically fails since he cannot perpetuate the judge's toxic expectations. Even though his toxic activities of thrill seeking and fighting seemingly provide initial satisfaction, the kid fails and turns into an outcast.

By exposing cowboy mythology and deploying it to construct alternative masculinities, McCarthy questions the Frontier Thesis and Manifest Destiny while disrupting the toxic assumptions about manhood and masculine identities they were intended to uphold. Blood Meridian self-consciously enters the Western genre's violent narrative tradition in order to undermine readers' expectations by deploying violence in untraditional ways. The new vision McCarthy presents in Blood Meridian challenges the development of American national identity based on the hysterical and vicious conquest of impoverished, discriminated, oppressed, and racialized Others and exploited, feminized nature. In other words, McCarthy discourages those cowboy traits that are toxic or deadly to women, children, animals, and all other living things, and reinforces alternative masculinities.

1 R. W. Connell and Roger Horrocks used the term "toxic masculinity" in the 1980s and this idea of toxicity was a core tenet of the mythopoetic men's movement even though it was potentially understood in different and varying ways from today's usage of the term. The mythopoets believed that industrial revolution, "the loss of camaraderie on over competitive workplaces," the feminist movements brought about the loss of "deep" or "real" masculinity (Bly 9). McCarthy's novel thus emerges at the very inception of the terminology. 
McCarthy's Blood Meridian raises this awareness by critiquing the official, mythologized history of American manhood and its toxic narrative of the frontier past. Since American men have always looked to the West to discover or (re)invent the central pillars of their masculine identity, McCarthy deliberately scrutinizes failed cowboyism and how it has undermined American manhood. By responding to the masculinity crisis explored by scholars such as Harry Brod, Michael Messner, and Michael Kimmel, McCarthy asks readers to rethink gender roles, especially cowboy manhood and its toxic manifestations. He demands that American men stop mythologizing and instead assume responsibility for nature, women and children. As his novel illustrates, the adventurous, independent, courageous, stoic and strong cowboy of the past must yield to a more cautious and empathetic model. McCarthy makes it clear that a non-toxic masculinity is not only possible, but the only one that is sustainable.

\section{The Western Genre and its Transgression in Blood Meridian}

Western novels have appeared in numerous literary forms, ranging from the historical novels of Alfred Bertram Guthrie, to the frontier stories of Louis L'Amour. In the 1970s and 1980s, flustered by an era of social and political turmoil, western writers such as Elmer Kelton, G. Clifton Wisler, and Cormac McCarthy started to examine the well-known cowboy myth and frontier masculinity. These revisionist novelists broke "with the easy heroism of the traditional western novel" and "divulge[d] previously ignored realities while rejecting illusions previously cherished" (Haslam 1167). They shaped a new western trend, "trying to rub their eyes clear of mythic and legendary cobwebs, [to] see straight to the actual" (Kittredge 177). As Stephen McVeigh elucidates, the texts of these contemporary western novelists went "further than simply questioning the values of and techniques of the genre" (152), as the title of Sara Spurgeon's Exploding the Western: Myths of Empire on the Postmodern Frontier (2005) suggests. Writing in the latter half of the twentieth century, Cormac McCarthy shares many of the same concerns regarding American masculinity as his contemporaries-authors such as Sam Shepard, E.L. Doctorow, Thomas Pynchon, Ishmael Reed, and Gerald Vizenor.

Starting his career in the mid-1960s, McCarthy published his gothic fiction-The Orchard Keeper (1965), Outer Dark (1968), Child of God (1973), and Suttree (1979) - in ambiguity. He was quite reclusive and was not interested in his publisher's promotional campaigns. He rejected inter- 
views, personal appearances, media coverage, as well as academic gatherings that could have made him a more popular writer much sooner. In "Cormac McCarthy's Venomous Fiction," Richard Woodward relays the sum total of what was then known by the general public about McCarthy's "mysterious" life:

McCarthy's silence about himself has spawned a host of legends about his background and whereabouts. Esquire magazine recently printed a list of rumors, including one that had him living under an oil derrick. For many years the sum of hard-core information about his early life could be found in an author's note to his first novel, The Orchard Keeper, published in 1965. It stated that he was born in Rhode Island in 1933; grew up outside Knoxville; attended parochial schools; entered the University of Tennessee, which he dropped out of; joined the Air Force in 1953 for four years; returned to the university, which he dropped out of again, and began to write novels in 1959. Add the publication dates of his books and awards, the marriages and divorces, a son born in 1962 and the move to the Southwest in 1974, and the relevant facts of his biography are complete.

For years, McCarthy's audience was limited to a group of gothic enthusiasts, mainly from the South. Indeed, McCarthy's southern gothic novels have been compared and contrasted with those of William Faulkner and Flannery O'Connor for their rhetoric and plots, in reviews and in book-length studies (by Guinn, Folks, Perkins and many others). Despite similarities, McCarthy's treatment of masculinity is different than Faulkner's and O'Connor's. McCarthy's men yearn to re-unite the body and the mind, despite psychic confusion deriving from childhood. Faulkner's and O'Connor's texts lament the loss of the comforting illusions of both honor and gentility from a bygone age. On the other hand, McCarthy's novels demonstrate the unraveling of old myths in relation to American manhood. Like Faulkner, McCarthy places a higher value upon masculine performance. Yet, McCarthy contributes nothing to the illusion of human progress. What makes McCarthy's gothic fiction different than its predecessors is his combination of the features of southern literature with border stories and Mexican folk culture.

Turning away from the American South of his earlier novels and towards the West, McCarthy spent fifteen years writing The Border Trilogy. If one also includes his first Western, Blood Meridian or The Evening Redness in the West (1985), which can rightfully be seen as a prologue to the trilogy, then almost half of his writing career has been devoted to western novels. Indeed, he appears, like critic Robert L. Jarrett points out, to have made "a sudden break with the past" and his "career in Southern fiction" (8)-a 
break that many critics note by dividing his fiction, as Wade Hall and Rick Wallach do, into "Southern" fiction and "Western" fiction (43). McCarthy comments on his interest in western novels in response to a question posed by The Wall Street Journal: "How [did] a man who was born in Rhode Island and grew up in Tennessee end up writing in and about the Southwest?" As McCarthy expresses,

I ended up in the Southwest because I knew that nobody had ever written about it. Besides Coca-Cola, the other thing that is universally known is cowboys and Indians. You can go to a mountain village in Mongolia and they'll know about cowboys. But nobody had taken it seriously, not in 200 years. I thought, here's a good subject. And it was. (Jurgensen)

As McCarthy explains, the Western and the cowboy have become a universal and international phenomenon, and have earned a place in American culture and iconography abroad "because they have provided a reliable vehicle for filmmakers and writers to explore thorny issues of American history and character" (Agresta 14). McCarthy deploys his Southwestern setting to explore southern literature's complicated transition from modernity to postmodernity, as he extends many of the tropes of southern literature (e.g. the gothic, graphic violence, and dialect) into his western novels, rendering his Southwest in every way an extension of his South.

The passing way of life on the ranch continues to be a motif of the nineteenth century "golden age" of cowboys, which McCarthy's cowboys, in particular, yearn to maintain. As A. O. Scott explicates in The New York Times, McCarthy's "intent is not to demystify the literature of the past, but to recapture something of its mystery and power-to breathe new life into a rather shopworn mythology" (26). McCarthy's characters cling to chivalric codes and manners while reluctantly facing the dawning of a new age. Thus, McCarthy not only brought something original to American literature-especially to the western novel-but he has also created an introspective vehicle of self-discovery for American men through his literary depiction of a country and its cowboy mythology. ${ }^{2}$

2 While this might explain why Cormac McCarthy's protagonists are mostly male, it has certainly not spared him from severe criticism, as he has failed to create convincing female characters. The women in his western novels - nearly all of them Mexican - are either silent, maternal, and goodhearted wives, most of whom happen to be dead or otherwise existing only as objects of memory, or miserable servants and sex workers, elusive girls joined to the protagonists in tragic passion. Thus, Nell Sullivan, Lydia Cooper and Harriet Poppy Stilley claim that McCarthy's fiction has misogynistic leanings that "contain feminine 
As archival evidence suggests, while composing Blood Meridian, McCarthy conducted comprehensive research, and used numerous confessions, memoirs and legal documents in his work. In a handwritten letter to Howard Woolmer dated June 26, 1977, McCarthy writes, "I'm in Tucson working on my 'western,' long book supposed to be out this year, but maybe not." In February of the same year, in a previous letter to Woolmer, he had written, 'I'm working on a western - based loosely on historical events, Mexico in 1849-illustrated with about 2 dozen period prints - woodcuts mostly. The book is essentially finished (300 pp.) - but needs to be completely rewritten" (Cormac McCarthy Papers, Box 19, Folder 6). McCarthy reveals the fact that he wrote Blood Meridian after his research on Mexican and American records on the Mexican-American War (1846-1848) and his education in Spanish. He also borrowed elements from books based on historical figures such as Captain Glanton and his scalp-hunters, and Samuel Chamberlain's My Confession (1860), an autobiographical work penned by a man who fought in the war with Mexico, and then enlisted in the Glanton gang as a mercenary. James O. Pattie's The Personal Narrative (1859), which glorifies cowboy masculinity and cowboy adventure and camaraderie in the Mexican-American war, was also a source.

The novel focuses on the life of a fourteen-year-old boy named "the kid." The narrative trajectory of the novel concerns the wanderings of this nameless child from the hills of Tennessee into the "immense and bloodslaked waste" of the American frontier - an experience that marks his initiation into manhood (McCarthy, Blood 177). Its opening pages present an account of the protagonist's early life in Tennessee, his quest to Texas, and "his recruitment by a troop of filibusters most of whom are murdered by a force of Comanches as the quest makes its way to Mexico" (12). In order to reassert his masculinity, the protagonist decides to accompany Captain Glanton's band of scalp-hunters, "who have a contract to provide the Mexicans with the hair of Apache raiders preying on isolated borderland villages and towns" (78).

This is how the gang starts its gory campaign of devastation and toxicity, which lasts almost a year and several hundred pages of the novel. The

power and obviate women" (Sullivan 170). She argues that McCarthy rarely focuses on female characters in his fiction and when they do exist, they are not as fleshed-out or fully articulated as his cowboy characters. In other words, they are representational rather than realistic. 
final chapter of Blood Meridian presents a summary of the twenty-eight years of the kid's quest and his death in a toilet "at the hands of his old comrade-in-arms, the seven-foot tall three-hundred-pound hairless albino Judge Holden," who is "a man of incredible savagery, and great intellectual facility" (234). At one point in the novel, he evokes the malevolent whiteness and sprawling enormity of Moby Dick, and is depicted as "pale and bloated manatee" (167) - a direct reference to Herman Melville's MobyDick. ${ }^{3}$ At the very end of the novel, he becomes the only survivor of the gang, and a one-page epilogue, which is essentially a parable of the frontier, concludes the work.

In the classic Western, a self-reliant, heroic American cowboy typically takes center stage. He is seemingly unswayed by the influences of modernization and industrialization that were changing America during the nineteenth century. In The Strenuous Life (1901), Theodore Roosevelt shared the fear of many of his contemporaries that "declining birth rates among white upper class women would eventually lead to race suicide if something was not done to reverse the trend" (14). Thus, he advocated "the virtues of the strenuous life on the Western frontier" (15). In order to encourage the trend, Roosevelt wrote The Winning of the West (1889-1896), in which he asserts that "western conquest was the crowning and greatest achievement of a series of mighty movements" (22). He argues that "in the struggle for existence that prevailed on the frontier, victory would go to the stronger race," of course with the help of the white cowboys (24). Thus, the West was won by American men who were "rugged, tough, adventurous, resourceful and exceptional" (22). As Richard Slotkin states in Gunfighter Nation: The Myth of the Frontier in Twentieth-Century America, "in Roosevelt's fanciful 'race-history' of the nation, a heterogeneous mix of Anglo, German, Dutch, Scots-Irish, and other so-called Teutonic races were fused into one people and this hybrid super race was winning the west" (44). Yet, as Slotkin points out, Roosevelt's range of races was extremely discriminatory; it disregarded other masculinities, such as those of black, Native American, Mexican and Chinese cowboys in the formation of the frontier. As a matter of fact, Roosevelt's frontier myth was entirely connected to

3 The judge, with his enormous size, whiteness, and ultimate eeriness resembles Melville's whale. The presence of the quote in both his personal papers and in the novel itself confirms the sense of so many readers that McCarthy had Moby Dick in mind when writing Blood Meridian (Cormac McCarthy Papers, Box 19, Folder 13). 
Frederick Jackson Turner's white, exclusory and totalizing frontier thesis, "a story whose power," as Bill Brown comments,

is precisely that of epic containment - the production of a history of national consolidation so monumental that it diminishes other events and obscures other realities of the West. The narration of the West aestheticizes the genocidal foundation of the nation, turning conquest into a literary enterprise that screens out other violent episodes in the nation's history. (31)

Turner's frontier thesis, which supposedly links westward expansion to progress, fails since, among other things, it does not represent women and minorities, and promotes the exploitation of the land and its resources. The reality is that with the closing of the West came defeat, failure, death, destruction, and frustration.

As a "counter narrative to the overly sanitized rhetoric of Manifest Destiny" (Eaton 160), Blood Meridian poses the question: what is American masculinity? Its depiction of toxic masculinity and enormous brutality act as a counter myth that challenges patriarchy, cowboy masculinity, and the pernicious lies they propagate. The novel interrogates cowboy masculinity so thoroughly that even its western spaces degenerate; the landscape inherently threatens to consume the cowboys and transform them into something less than human, rather than encourage their masculinity as so many earlier Westerns do. In fact, in the novel the landscape and the cowboy intermingle: "as they rode [they] turned black in the sun from the blood on their clothes and their faces then paled slowly in the rising dust until they assumed once more the color of the land through which they passed" (McCarthy, Blood 161). In the course of the novel, the cowboys are described as "beings provoked out of the absolute rock and set nameless and at no remove from their own loomings to wander ravenous and doomed and mute as gorgons shambling the brutal wastes of Gondwanaland" (172). It is clear how the landscape and the cowboys who wander through it are deprived of identity and language, becoming little more than embodiments of "loomings." Here, McCarthy fashions a vision of America, of cowboy masculinity, and by extension a vision of the world from which there is no exit.

As an anti-Western, Blood Meridian is a violent treatment of frontier themes in American culture and literature. In an attempt to unravel the cowboy myths of the West, the novel questions the formation of national and regional masculinities and reveals the underside of frontier life. As Susan Kollin points out, unlike classical western narratives, 
Blood Meridian does not offer a region whose promise and possibility were somehow lost at a certain point in history, but a West fully corrupted from the moment Anglos arrived. The western landscape that is supposed to be a test of character, bringing out the best in the hero and the worst in the villain, is emptied of its sacred qualities, becoming instead a fully defiled, profaned space. And unlike Westerns that depict the region as a prelapsarian garden and space of retreat for the American hero, McCarthy's text features an anti-Edenic landscape whose ownership is violently contested and overturned by the group of mercenaries. (562)

As Kollin discusses, Blood Meridian has abundant depictions of the frontier as a "desecrated and violent terrain, with death serving as the most prevalent feature of this land-scape" (563). Thus, this violent description of the landscape and even the book's title indicate that the creation of a western identity is a bloody act. In other words, violence governs Blood Meridian. In one of his interviews, McCarthy clarifies his own philosophy of violence:

There's no such thing as life without bloodshed, ... I think the notion that the species can be improved in some way, that everyone could live in harmony, is a really dangerous idea. Those who are afflicted with this notion are the first ones to give up their souls, their freedom. Your desire that it be that way will enslave you and make your life vacuous. (Woodward 36)

In accordance with his philosophy, McCarthy does not advocate bloodless coexistence and fraternal bonding among his male characters. Instead, in his novel, he fictionalizes toxicity, which is embodied by the antagonist wholeheartedly. He highlights the fact that this toxic masculinity was not only an attitude, but also a demographic and geopolitical reality of frontier culture and American masculinity.

\section{The Judge and His Toxic Philosophies}

Within the lawless state of toxicity, Judge Holden functions as the anchor of toxic masculinity. He only appears in the last twenty-six pages of Samuel Chamberlain's My Confessions (1860), but plays a much larger role in Blood Meridian. According to Chamberlain's memoir, there

was a man of gigantic size called 'Judge' Holden of Texas. . . . He stood six feet six in his moccasins, had a large fleshy frame, a dull tallow face destitute of hair and all expression. His desire was blood and women. . . . Holden was by far the best-educated man in 
northern Mexico; he conversed with all in their own language, spoke in several Indian lingos, at a fandango would take the Harp or Guitar from the hands of the musicians and charm all with his wonderful performance, and out-waltz any poblano of the ball. He was "plum centre" with rifle or revolver, a daring horseman, acquainted with the nature of all the strange plants and their botanical names, great in Geology and Mineralogy, in short another Admirable Crichton, and with all an arrant coward. (271-272)

McCarthy's antagonist possesses all these traits, except fearfulness. He is a dancer, politician, lawyer, musician, scientist, magician, naturalist and he gives commands in five languages. McCarthy also attributes him with more violent characteristics. Echoing My Confessions, the ex-priest Tobin portrays Holden in the novel as

That great hairless thing. You wouldnt think to look at him that he could outdance the devil himself now would ye? . . . And fiddle. He's the greatest fiddler I ever heard and that's an end on it. The greatest. He can cut a trail, shoot a rifle, ride a horse, track a deer. He's been all over the world. Him and the governor [Trias of Chihuahua] they sat up till breakfast and it was Paris this and London that in five Languages, you'd have give something to of heard them. (McCarthy 123)

McCarthy takes the judge out of the self-aggrandizing stories of Chamberlain's memoir and embodies him with toxic masculinity. His existence in the novel serves as a powerful agent through which other cowboys are subjected to toxic authority. The reader witnesses this act when the cowboys willingly accept his toxic philosophies, and thereby symbolically submit to his ideological framework of power, and control:

In the afternoon [the judge] sat in the compound breaking ore samples with a hammer, . . holding an extemporary lecture in geology to a small gathering who nodded and spat. A few would quote him scripture to confound his ordering up of eons out of the ancient chaos and other apostate supposings. The judge smiled.

Books lie, he said.

God dont lie.

No, said the judge. He does not. And these are his words.

He held up a chunk of rock.

He speaks in stones and trees, the bones of things.

The squatters in their rags nodded among themselves and were soon reckoning him correct, this man of learning, in all his speculations, and this the judge encouraged until they were right proselytes of the new order whereupon he laughed at them for fools. (McCarthy 122-123) 
The judge holds the power to sanction and validate the ideas they already possess, or to set different rules of obedience for the cowboys. This is mainly because the judge has mastered the art of marking and representation. As a doctor of philosophy, he travels with other cowboys, and gathers, catalogs and draws numerous natural and historical phenomena. He collects rare butterflies, kills and stuffs animals; he can instruct on geology, ancient Greece and the exodus of the Anasazi. His education on geology separates him intellectually and spiritually from the other cowboys. As Dan Moos states, he "allows only his vision of the things into his notebooks. If the object is inanimate, he must destroy it. If it is alive, he must destroy its animate qualities, its life" (28). As the judge claims, "the freedom of birds is an insult to me. I'd have them all in zoos" (199). According to this understanding, "the representation of object validates its existence; only through representation can some object be comprehended and thus contained" (Moos 29). He sketches "potsherds, bone tools and a sixteenth-century footpiece from a suit of armor" that he has detected in the desert. After evaluating and drawing, he puts them into the fire, declaring his intention to expunge them from the memory of men: Much satisfied with the world, as if his counsel had been sought at its creation" (McCarthy 140). In the Hueco Tanks, he wanders among the petroglyphs, copying out those certain ones into his book to take away with him, and before he departs, he annihilates "one particular design" (173). He retains control over everything through distortion of the original sources. His representations are almost perpetually accompanied by acts of violence and toxicity, and he destroys anything that challenges his authority and toxic philosophies.

Throughout the novel, the judge celebrates his toxic masculinity. Indeed, this toxicity is even inscribed upon the land itself, where the judge and the cowboys find "graven on the rocks above them pictographs of horse and cougar and turtle and the mounted Spaniards helmeted and bucklered and contemptuous of stone and silence and time itself" (145). As Ken Hanssen puts it,

cumulatively, all these cultural artifacts and traces not only ground the narrative in a specific historical moment, but also establish it within the larger progression of Western imperialism, a position that challenges the reader to consider the depredations of the Glanton gang not merely as isolated instances of barbarous excess but the inevitable expression of a Western culture predicated on genocidal violence. (185) 
In the novel, the judge appears to legitimize westward expansion when he claims that "all progression from a higher to lower order are marked by ruins and mystery and a residue of nameless rage" (147). His philosophy in demonstrating the origins of warfare is terrifying. He claims that "before man was, war waited for him" (240). He believes that "war is the testing of one's will and the ultimate game" (250). By reasoning that "war is god" (250), he considers war to be unavoidable and eternal - a natural drive that advocates hegemony and superiority and destroys all other masculinities. As he claims, "even in this world more things exist without your knowledge than with it and the order in creation which you see is that which you have put there, like a string in a maze, so that you shall not lose your way" (206).

With these words, the judge instructs his marauding followers-those cowboys who have aligned themselves with the judge's toxic pursuitsabout the nature of the world. The world, the judge argues, is chaotic and inherently without order; whatever order it appears to have is an order American men bring to it, which is narrated as a mythology of their own creation. The stories they tell-the manhood myths they develop and pass down to succeeding generations - are complicated, yet fragile, inventions because mythmaking is an act of imposing temporary order on a permanently disorganized world.

Since the kid is illiterate, he is astounded by the judge at the beginning of the novel. As George Guillemin argues, "the kid remains mostly silent and talks only in random, monosyllabic utterances hardly enough to sustain a dialogue. It is the narrator who speaks for, but not though the kid, while the judge monopolizes the novel's monologues" (255). Since the narrator is not assertive in the text, the judge and his toxicity dominate the narrative. He appreciates textuality, masculine verbosity and language as much as he appreciates violence. Thus, like the protagonist, the reader is also exposed to the toxic philosophies of the judge and can either choose to internalize or reject them.

The judge is particularly toxic when he performs masculinity that only values himself and his ability to do harm to others. The harm of toxic masculinity is amplified when he is in a position of dominance. His standards of toxic masculinity are impossible to comply with, and the inability to meet his lofty standards, to become a "true man," only enhances the toxicity. The cowboys who are desperate to attain these standards and the judge's approval act out violently in the novel. As the captain of the gang, mentor and judge of toxicity on the frontier, he explains and presents ethical justi- 
fications for the toxic activities the cowboys commit, which initially makes him irresistible to the kid. As Joshua J. Masters explains,

the kid finally lacks the Adamic capacity to name and create, and his illiteracy ... functions as a defining feature; he lacks the judge's textual capabilities. The judge claims that language and the knowledge necessary to apply it are the keys to creating and preserving power; thus, the kid's lack of that text-making ability engenders his failure and leads to his death. (35)

The illiterate kid becomes a symbol of the failed cowboy since he cannot live up to the judge's toxic language and philosophies. Even though he is associated with the gang and presumably takes part in scalping and other violent acts they perpetuate, he is condemned by the judge who claims; "there's a flawed place in the fabric of your heart. Do you think I could know? You alone were mutinous. You alone reserved in your soul some corner of clemency for the heathen" (312).

For the judge, the kid's resistance to toxic masculinity indicates the treachery of a father by a son. Since he rejects the judge's toxic philosophies, he deserves to die. According to Jay Ellis, "the judge's verbal virtuosity overwhelms the indifferent narrator who never morally comments on the events of the novel. The narrator seems to invite the reader to make his or her judgements and to assign meaning to the text, thus situating her or him as a culpable participant in the carnage" (25). Similarly, George Guillemin states that "nowhere in the novel does the narrative voice devote itself to the question of ethics, not even by pointing out the conspicuous absence of moral positions" (241). The lack of "moral positions" also encourages the reader's to resist the judge's toxic philosophies, which will become meaningful in the epilogue of the novel.

\section{The Kid as a Failed Cowboy}

Cormac McCarthy's description of the cowboys' satyromania as an embodiment of toxic masculinity has, over the years, received a great deal of criticism. For instance, Robert L. Jarrett claims that Blood Meridian is "pornographically violent" (32). Steve Shaviro states that the Western "sings hymns of violence, its gorgeous language commemorating slaughter in all its sumptuousness and splendor" (143). Caryn James points out that this sexual, masculine toxicity "comes at the reader like a slap in the face." Denis Donoghue calls the novel's violence "excruciating," while 
Leo Daugherty asserts that there is no sense in reading "such an excessive, doom-obsessed, bone-chilling novel of blood" (169). However, McCarthy utilizes violence and toxicity to tarnish the cowboy narrative and to illustrate the futility of this kind of masculinity. In his analysis of anti-heroes in Westerns, Jesse Matz points out that

characters in modern Western novels are not heroes: they are rarely singled out for their superior traits, and they rarely achieve much. If anything, they are worse than normal. . . In the larger scheme of things, there is a long and steep descent from the epic heroes of myth and legend to the anti-heroes of modern fiction. The former were far better than average, superior to their environments, and destined for triumph; the latter are weak, disaffected, and passive, undone by circumstance, and lucky to make it through at all. (45)

Instead of allowing his protagonist to claim redemption though acts of conquering triumph, McCarthy portrays a cowboy who does nothing but pursue a cowboy identity in the name of heroism. The protagonist does not perform the toxic masculinity the judge expects of a cowboy. Thus, he emerges as an apathetic anti-hero in the context of toxic masculinity.

As Jenni Calder argues, more than any other genre, the Western is based on creating "a certain kind of cultural hero. The code is a strict one: decency, courage, patience, loyalty, not just for their own sake but because they are the things that make life bearable" (177). Calder adds that traditionally, the cowboy figure "has a certain boyishness and charm; any elements that might be considered unwholesome have to be purged from his character in order to allow him to remain sympathetic with audiences" (198). One would expect this from the kid, but McCarthy subverts this archetype with his protagonist, much like he subverts the entire Western genre with Blood Meridian. By doing so, the novel becomes what Richard Slotkin calls "a serious object of inquiry" (380). As he conveys, "only at the moment when it develops 'adult' topics, when it begins to mediate on subjects such as the problems of frontier violence or the hero's ambivalence toward the codes" (380), is the Western unmooring itself from the frivolousness of the genre-something that Blood Meridian accomplishes through its examination of the senseless violence and brutal sexuality that characterize toxic masculinity.

McCarthy continues his critique of the genre by questioning the figure of the child through the kid. The protagonist evokes the image of the "man with no name," a loner and outlaw on the American frontier. By alluding to romanticized historical outlaws such as Billy the Kid and Jesse James, 
McCarthy once again questions the masculine characteristics attributed to these Wild West rebels. ${ }^{4}$ Interestingly, he does not capitalize his protagonist's name. He is no more, has little if any significance, and the cowboy hero is dissolving into forgotten chapters of American history. Depicted as a character known only as "the kid," whose lack of a surname indicates his rootlessness, the protagonist begins his quest out of concern for his masculinity. As Robert L. Jarrett argues, like Huckleberry Finn, the kid "undertakes the American masculine romance of lighting out for the territory" (64). The characterization of the protagonist as a cultural descendant of Huckleberry Finn is central to this construction of American masculinity. Huckleberry Finn's literary doppelganger, the kid, sets off for the frontier in order to test "whether the stuff of creation may be shaped to man's will or whether his own heart is not another kind of clay" (McCarthy, Blood 5). His father "has been a schoolmaster," "lies in drink," and "quotes from poets whose names are now lost" (4). In sharp contrast, the protagonist "can neither read nor write," but "in him broods already a taste of mindless violence" (4). Consequently, he heads out alone to discover himself and his masculinity by escaping from his sozzled father at age thirteen, and "will not see again the freezing kitchenhouse in the predawn dark" (4).

The kid's coming of age begins when he finds a job on a ship. At the gateway to the West in St. Louis, he boards a "flatboat" that much like Huck, takes him on a journey down the Mississippi River, leading him to the city of New Orleans (4). Here, at the intersection of three empires (French, Spanish and American), he is "finally divested of all that he has been," and starts to wander the streets and "hears tongues he has not heard before" (4). $\mathrm{He}$ "lives in a room above a courtyard behind a tavern and he comes down at night like some fairybook beast to fight with the sailors. He is not big but he has big wrists, big hands" (McCarthy 3-4). Initially in the narrative, the protagonist tries to prove his masculinity by enacting and sustaining violence. He fights with a group of sailors, and his manhood is affirmed. During his quest, he encounters "parricide in a crossroads hamlet" (4). It is as if

4 In his correspondence with Howard Woolmer, McCarthy reveals that while writing the novel, he read Michael Ondaatje's The Collected Works of Billy the Kid: Left Handed Poems (1970), a revisionist Western that resonates in McCarthy's text. A narrative of the life of Billy the Kid through poetry, prose, and historical photographs, The Collected Works of Billy the Kid: Left Handed Poems foregrounds the violence of the West in ways that call to mind McCarthy's forays into the Western genre (Cormac McCarthy Papers, Box 35, Folder 1). 
the protagonist's correlation with parricide has disconnected him from his family, permanently cutting his metaphorical umbilical cord. "Only now" the narrator scrutinizes, "is the child finally divested of all that he has been. His origins are become as remote as his destiny" (5).

Suddenly cut off from all the conventional markers of identity, the kid enters into the business of westward expansion. He leaves Mississippi and goes to Texas, where he becomes a member of a gang of scalp-hunters who intend to slaughter everyone in their path. The opportunity to travel with the cowboys seems like a gift from heaven for it allows the protagonist to exert fully his manliness. That is why he engages in homicidal acts early in the novel, just like the rest of the gang. Later in the narrative, the protagonist is sentenced for wearing White's clothes and the children make fun of him. Feeling emasculated, his reaction is a violent one: "He picked one [a rock] from the dust the size of an egg and with it dropped a small child cleanly from the wall with no sound other than the muted thud of its own landing on the far side" (72).

Unlike the righteous cowboys of the Old West, the kid is unvirtuous and dishonest as he combats the other members of the scruffy gang. He is certainly not a symbol of western promise and its future. Instead, he is an "allegorical figure for a depraved America - the youthful nation-which is portrayed here as fallen and corrupted from its very inception" (Kollin 566). While presenting the young protagonist in this brutal manner, the novel also undermines a pivotal theme in American literary history. In The Reign of Wonder: Naivety and Reality in American Literature (2010), Tony Tanner claims that in the nineteenth century, American literature relied on a fascination with the state of youth. As he describes,

the naïve vision of the child has been put to far-ranging uses in American literary history. A major problem facing [white] American writers was simply, overwhelmingly, the need to recognize and contain a new continent. The wondering vision was adopted as a prime method of inclusion and assimilation and still functions as the preferred way of dealing with experience and confronting existence. (10)

Thus, in American literature, "the reign of wonder" is used to explain the social and cultural demands of hegemonic society while promoting westward expansion.

Even though McCarthy uses the figure of youth in his Gothic and Western fiction, Blood Meridian begins with a parody of the "childlike wonder" often found in American literature: 
See the child. He is pale and thin, he wears a thin and ragged linen shirt. He stokes the scullery fire....

At fourteen he runs away. He will not see again the freezing kitchen house in the predawn dark....

A year later, he is in Saint Louis. He is taken on for New Orleans abroad a flatboat. Forty-two days on the river. At night the steamboats hoot trudge past through the black waters all alight like cities adrift. They break up the float and sell the lumber and he walks in the streets and hears tongues he has not heard before. He lives in a room above a courtyard behind a tavern and he comes down at night like some fairybook beast to fight with the sailors. (3-4)

Here, the narrator uses the singsong voice of children's literature in order to evoke an image of archetypal innocence through simple storybook language. Images of children or childishness recur throughout the novel so that this imagery constitutes a central allegorical theme in the novel. By deploying sententious language and keeping descriptions of the protagonist to a minimum, the novel seems to lack sophistication. However, in this context, this writing style actually presents a parody of the innocent wonder tradition, which is enforced when the protagonist wanders further and further away from this simplicity to toxicity.

Comparing and contrasting the protagonist with Huckleberry Finn - the most well-known boy narrator in American literature - as an immoral and unprincipled reversal of this character, some critics argue that "McCarthy unsettles the comfort and solace that the youthful point of view typically provides Anglo audiences" (Phillips 439). In his description of the protagonist, he describes him as someone who "can neither read nor write and in him broods already a taste for mindless violence. All history presents in that visage, the child the father of the man" (4). Depicting the West and its history as corrupt, and the toxicity in the protagonist's development a result of this, McCarthy's kid requires "no fall from grace" and demands no affection from readers. In the rest of the novel, the kid embodies toxic behavior and executes carnage, becoming as violent and as toxic as the adult men. Unlike classic Western narratives, Blood Meridian considers youth as dangerous and as dispensable as any of the older men in the novel. The protagonist, for example, is described as "threatening from his birth," since his mother becomes his first sacrifice, a mother "who did incubate in her own bosom the creature who would carry her off" (4).

McCarthy also problematizes the cowboy's sexuality and gender performance. Even though the kid does his best, he cannot experience masculinity at the exaggerated level of the judge and thus cannot become a "real 
man." According to the judge, the only cowboy who can dance is one "who has seen horror in the round and learned at last that it speaks to his inmost heart" (331). Even though the judge asks him to dance naked in front of him, the kid refuses to engage in this queer moment. However, according to the judge's toxic philosophy, dancing naked in front of other men is not queer, but rather a sign of confidence in one's masculinity and heterosexuality; although, as I will discuss at the end of this article, some critics also interpret this as signaling the judge's sexual crimes (pedophilia and rape, followed by murder), which further toxifies the masculinity he represents. Nevertheless, the protagonist is doubtful about his own sexuality, which may be one reason why he refuses. At one point in the narrative, like Holden Caufiled in The Catcher in Rye, the kid cannot perform sexually with a sex worker. As Jay Ellis states, "McCarthy shows us the kid's failure sexually. The kid's inability to perform with the prostitute ... makes it clear that in place of the judge's dance, the kid has no alternative procreative power. In this sense, he is still 'the kid' in relation to the judge as authority" (165). He becomes a foil for the judge's toxic masculinity and fails to live up to his masculine standard. Even though the protagonist attempts to construct a masculine identity, his attempts remain insufficient and misguided outside the toxic philosophies of the judge. His inability to construct an alternative definition of masculinity situates him as an abortive cowboy who has failed in his quest.

\section{A Voice of Dissent against Toxic Masculinity}

Although he takes part in the violence of the Glanton gang, the kid ultimately abandons them, trying to develop an alternative masculine identity beyond the judge. He starts to believe that the idea that "war is God" contributes to toxic masculinity, wickedness and depravity. He also realizes that one does not need to be a "demigod" to be a cowboy (333). Even though his illiteracy prevents him from standing up to the judge, he is able to escape his toxic doctrines. According to Joshua Masters, "because the kid has preserved a capacity for judgement, mercy, and morality, he has preserved some portion of himself outside of the judge's textual domain" (35). Here, McCarthy problematizes the stoic and unemotional American cowboy. By exposing the kid's growing attempts to connect and be compassionate with alternative masculinities, McCarthy questions the link between the morality of cowboyism and toxic masculinity. At the end of the novel, the kid has 
realized that "his actions are incorrect" and he no more believes that "it is the world of man which is filled with chaos and terror and war" (Hillier 10). As Russell Hillier points out, the kids desire to communicate with and old lady, the buffalo hunter, and the bone-picker Elrod reflect his determination and consistency in disapproving the judge's toxicity, malevolence and defying his authority (10). The kid figures out that the judge's toxic philosophies has robbed him of being a benevolent cowboy and of being true to himself. Hence, from now on, he is able to work through his emotional toxicity to learn healthy coping mechanisms. In other words, he has learned to engage with his emotions, rather than remaining stoic during times of emotional vulnerability. As opposed to the rest of the gang "who accept the judge as their de facto leader" (McCarthy 306), the kid rebuffs him. The judge realizes the kid's intention in the following passage:

You came forward . . . to take part in a work. But you were a witness against yourself. You sat in judgement on your own deeds. You put your own allowances before the judgements of history and you broke with the body of which you were pledged a part and poisoned it in all its enterprise. (307)

He assumes that the kid expresses his distaste because he is weak. On the contrary; the kid realizes that he must repudiate the toxic doctrines of the judge, despite the fact that with this repudiation comes an admission of weakness. He figures out that the judge is so stuck in the toxic masculinity mud that he does not realize there is nothing more masculine than dedicating himself to the healthier and positive upbringing of cowboy generation. In other words, he contributes to toxic and harmful behavior that does not benefit him, other cowboys, or society in general. The cowboys that he assists need to experience the full range of human emotions, not rage, aggression, violence, and hypermasculinity.

As Jay Ellis states, the kid "represents the hope that in every man there does not live an instinct for violence, racism, and destruction, that in some there exists an instinct for salvation and compassion and healing. Even though that person might not recognize it as such" (128). Thus, the protagonist's repudiation of the judge's toxic masculinity suggests hope for an alternative masculinity that does not subjugate women and other masculinities though oppression and violence. In the narrative, even though he has the opportunity to murder the judge, he does not. Yet the judge does not see this as a show of strength, but as another sign of weakness: "no assassin, called the judge. And no partisan either. There's a flawed place in the fabric of your heart. Do you think I could not know? You alone were mutinous. 
You alone reserved in your soul some corner of clemency for the heathen" (300). By resisting the judge's toxic masculinity, which is based on barbarism, racism and homophobia, and preferring to escape to the wilderness, the kid "becomes a guide for each traveler passing through the wilderness" (Spurgeon 96). Through his escape, he establishes a definition of masculinity that includes benevolence, empathy and tenderness. The kid explores this alternative masculinity when he tries to admit his violation of the land to a dead Native American woman:

He saw alone and upright in a small niche in the rocks an old woman kneeling in a faded rebozo with her eyes cast down. ... She was very old and her face was gray and leathery and sand had collected in the folds of her clothing. . . . He spoke to her in a low voice. He told her that he was an American and that he was a long way from the country of his birth and that he had no family and that he had traveled much and seen many things and at war and endured hardships. He told her that he would convey her to a safe place ... or she would surely die. (315)

He unburdens himself as an "American," comes to terms with the toxic philosophies of the judge, and even apologizes to Mexicans and Native Americans for his country's violation of their territories. Although he initially takes part in the carnage the judge espouses, he ultimately provides a voice of dissent, tries to find alternatives to toxic masculinity, and creates a possible life outside the toxic philosophies that at one point he had embraced.

In the final part of the novel, McCarthy depicts the last twenty-eight years of the kid's traumatic and agonizing life in prison. After evading the judge, the kid is sentenced in California, and goes through a serious breakdown as a result of his dreadful involvement in the gang. As the narrator notes, "in his cell he began to speak with a strange urgency of things few men have seen in a lifetime and his jailers said that his mind had come uncottered by the acts of blood in which he had participated" (317). He escaped the judge to find an alternative masculinity, but saw more of the same world into which he had been initiated. In 1878, the kid returns to Texas and encounters the judge in a bar, who comments:

The last of the true. The last of the true. I'd say they are all gone under now saving me and thee. Would you not?

He tried to see past him. That great corpus enshadowed him from all beyond. He could hear the woman announcing the commencement of dancing in the hall to the rear.

And some are not yet born who shall have cause to curse the Dauphin's soul, said the judge. He turned slightly. Plenty of time for the dance.

I aint studyin no dance. 
The judge smiled.

You're here for the dance, he said.

I got to go.

The judge looked aggrieved. Go? Drink up, he said. Drink up. This night thy soul may be required of thee. (334)

Once again, the judge enunciates his toxic doctrines through a comprehensive lecture on the act of "dancing." Nevertheless, the protagonist is not affected by this annoying and bloody "celebration," which also involves the killing of a dancing bear (334). Because of his toxic nature, he abuses and exploits animals. In order to make himself look brave and overbearing on this occasion, he psychically torments the harmless bear.

At the very end of the novel, the narrative shifts from the outhouse toilet to the judge who "dances in light and in shadow and he is a great favorite. $\mathrm{He}$ never sleeps, the judge. He is dancing, dancing. He says that he will never die" (335). As his dance illustrates, the kid cannot heroically construct a toxic masculinity in the eye of the Judge, a suzerain of toxicity of the western frontier. He rejects the judge's doctrine that a cowboy must internalize war as "his god" in order to dance "the dance of masculinity" (330). "Only that man who has offered up himself entire to the blood of war," the narrator comments, "who has been to the floor of the pit and seen horror on the round and learned at last that it speaks to his inmost heart, only that man can dance" (331). Here, it seems as if the judge rapes and kills him.

In their analysis of the ending of the novel, critics surprisingly deal very little with the kid and the humiliation he feels because of his desire for an alternative masculinity. In The Achievement of Cormac McCarthy, Vereen $\mathrm{M}$. Bell states that the antagonist is a "murderer of innocents-of a Mexican boy, of an Indian girl, of a mere puppy, and of the kid" (135). Tom Pilkington claims that the protagonist's end "is presided over by Judge Holden, a bloated angel of war and death" (318). Likewise, in "The Dance of History in Cormac McCarthy's Blood Meridian," John Emil Sepich argues that the protagonist "meets death in an outhouse in Griffin, Texas in 1878, at the hands of a former compatriot named Judge Holden" and attributes an argument on the "motive behind the murder" (16). They are inclined to see that at the end of the novel, the judge rapes and slaughters the protagonist in the jakes in Griffin, Texas.

Samuel Chamberlain's My Confession-the unique account of the historic character Judge Holden-provides a similar account of the Judge. Chamberlain points out that the judge's "desire was blood and women," 
which included raping and murdering female children. He illustrates his point with an episode in which the Judge was "suspected of having foully violated and murdered a girl of ten" (271). However, in Blood Meridian McCarthy changes the victimized children's sex. In other words, his victims, who suffer the fallout of the judge's toxic masculinity, are all male. McCarthy's alteration of the historic account of Judge Holden contributes to his intention of highlighting the kid's alternative, nontoxic, masculine sensibilities, as well as his rejection of the androcentric, hypermasculine, hyperheterosexual nature of the frontier experience.

As a cowboy, the kid has lived in the mountains, on ranches, as well as on prairies for over thirty years. Thus, the judge's toxic masculinity can also be considered as a violation of the landscape that epitomizes his freedom. As Vince Brewton argues, the kid embodies the physical and spiritual sustenance of the West (129). When he is in open spaces, he has a chance to defend his masculine honor as he does a few times in the narrative. Yet, the jake episode at the end of the novel indicates his inability to move beyond these open spaces, and represents the immensity of the antagonist's threat to the kid's alternative masculine identity. After killing the kid, the judge dances naked "saying that he will never die," claiming immortal power through his body:

And they are dancing, the board floor slamming under the jackboots and the fiddlers grinning hideously over their canted pieces. Towering over them all is the judge and he is naked dancing, his small feet lively and quick and now in doubletime and bowing to the ladies, huge and pale and hairless, like an enormous infant. He never sleeps, he says. He says he'll never die. ... He never sleeps, the judge. He is dancing, dancing. He says that he will never die. (335)

According to Patrick Shaw, "this triumph over the kid is what the exhibitionistic and homoerotic judge celebrates by dancing naked atop the wall," just as he had done after raping the other boys (118). Even though the protagonist is aware of the judge's toxic masculinity, he is ultimately powerless against it. The judge knows that the protagonist never thoroughly succumbed to his will and because "he cannot allow autonomous life to exist save by his dispensation" (McCarthy 199), he must ravage the protagonist as he ravages the little birds whose freedom "is such an insult to him" (199). His dance of immortality gives the message that the patriarchal system, which is reinforced by toxic masculinity, will dominate American society indefinitely. 
In conclusion, Blood Meridian exemplifies the demythologization process of the American West and cowboy masculinity. As a revisionist Western, it protests and exposes the once popular view of the frontier as a place of honor and romance. It depicts the ambiguity and anxiety surrounding frontier masculinity and criticizes the dominant toxic tropes of the western American imaginary as regressive. As opposed to the honor found in classical Westerns, failure and anti-romance are the key components of Blood Meridian. McCarthy exemplifies the contours and consequences of simplified, toxic forms of cowboy masculinity in the novel. Thus, McCarthy not only challenges the mythic codes and notions on which the genre usually relies, but also debunks frontier cowboy masculinity. As McCarthy illustrates, the cowboy is no longer the chivalric hero of the frontier. Rather, he is a peripatetic wanderer who gets caught in the mindless cycle of violence he encounters in the borderlands.

Blood Meridian is a dark novel, and depicts a malignant form of toxic masculinity born out of the violence of the American West, where women were few and toxic masculinity manifested itself in different ways. McCarthy illustrates the widespread and relentless physical and sexual violence that characterized the West through toxic masculinity. The novel's engagement with toxic masculinity differentiates it from traditional cowboy narratives. Thus, it functions as a satire of frontier myths - specifically of the toxic masculine codes and those white men who slaughtered $\mathrm{Na}$ tive Americans and Mexican Americans, animals and plants, even ancient petroglyphs, in its pursuit. McCarthy recalls both the traumatic violence of the American West and its place within American narratives of manhood and collective memory.

Because of its engagement with the implicit realities of the West, a legacy that is still exalted and eulogized by American men, Blood Meridian is a perfect example of how work in the field of Masculinity Studies is unraveling the official, mythologized history of American manhood and its reliance on toxicity. Through his novel, McCarthy "gives voice to its anonymous victims producing an encounter that, by breaking with traditional modes of understanding, creates new ways of gaining access to a historical catastrophe for those who attempt to witness it from afar" (Caruth 156). Such projects are imperative in Masculinity Studies since as the judge reminds the reader, "men's memories are uncertain and the past that was differs little from the past that was not" (McCarthy 330). By subverting the predominant mythico-historical narratives of the Frontier, the novel questions the con- 
sequences of American men's acceptance of archetypal cowboy myths and highlights the gap between the mythologized history of American manhood and its modern realities.

As so many headlines indicate, in contemporary American society, there is an urgent need for healthier masculinities that make sense in men's lives. Even a casual look at masculinity in today's America reveals that the masculinity crisis continues to exist in numerous forms. In Blood Meridian or The Evening Redness in the West, McCarthy addresses this issue critically and comprehensively, analyzing its mythic roots, dealing with its modern manifestations, and demythologizing many of the bedrock assumptions upon which American men have built an understanding of themselves. McCarthy offers deep and disturbing insights into cowboyism that continues to hold such sway over masculinities in the United States. Nevertheless, American men still feel the need to perform and posture. Living up to the expectations of social and ideological norms has not disappeared, which makes McCarthy's observations and interpretations all the more relevant and urgent. 


\section{Works Cited}

Agresta, Michael. "How the Western Was Lost (and Why It Matters).” The Atlantic, July 24, 2013, pp. 11-18.

Bell, Vereen M. The Achievement of Cormac McCarthy. Louisiana State University Press, 2008.

Bly, Robert. Iron John: A Book about Men. DaCapo Press, 2004.

Brewton, Vince. "The Changing Landscape of Violence in Cormac McCarthy's Early Novels and The Border Trilogy." Southern Literary Journal, vol. 37, no. 1, 2004, pp. 121143. Project Muse, doi.org/10.1353/slj.2005.0003.

Brown, Bill. "Reading the West: Cultural and Historical Background." Reading the West: An Anthology of Dime Westerns. Ed. Bill Brown. Bedford, 1997, pp.1-40.

Calder, Jenni. There must be a Lone Ranger: The Myth and Reality of the American Wild West. Abacus, 2016.

Campbell, Hugh. "Masculinity and Rural Life: An Introduction." Country Boys: Masculinity and Rural Life. Ed. Hugh Campbell, Michael Mayersfeld Bell, and Margaret Finney. $\quad$ Pennsylvania State University Press, 2006, pp. 1-22.

Campbell, Olivia. "The Men Taking Classes to Unlearn Toxic Masculinity." The Cut,December 13, 2017, www.thecut.com/2017/10/the-men-taking-classes-to-unlearntoxic-masculinity.html.

Caruth, Cathy. Trauma: Explorations in Memory. Johns Hopkins University Press, 1995.

Chamberlain, Samuel E. My Confessions, Harper and Brothers, 1956.

Connell, R. W. Masculinities. $3^{\text {rd }}$ ed., California University Press, 2005.

Cormac McCarthy Papers, McCarthy, Cormac. "Correspondence," Box 19, Folder 6, Southwestern Writers Collection, The Wittliff Collections, Texas State University at San Marcos.

---. McCarthy, Cormac. "Notes on Blood Meridian," Box 19, Folder 13, Southwestern Writers Collection, The Wittliff Collections, Texas State University at San Marcos.

---. McCarthy, Cormac. “Correspondence,” Box 35, Folder 1, Southwestern Writers Collection, The Wittliff Collections, Texas State University at San Marcos.

Cunnell, Howard. "Traditional Ideas of Masculinity are Poisoning Our Society. There is Another Way." The Guardian, November 11, 2017. www.theguardian.com/commentisfree/2017/may/15/power-violence-define-men-peace-masculinity.

Daugherty, Leo. "Gravers False and True: Blood Meridian as Gnostic Tragedy." Perspectives on Cormac McCarthy, Ed. Edwin T. Arnold and Dianne C. Luce, University Press of Mississippi, 1993, pp. 157-72.

Donoghue, Denis. "Dream Work." The New York Review of Books, June 24, 1993, www. nybooks.com/articles/archives/1993/jun/24/dream-work/.

Eaton, Mark A. "Dis(re)membered Bodies: Cormac McCarthy's Border Fiction." Modern Fiction Studies, vol. 49, no. 1, 2003, pp. 155-180. JSTOR, www.jstor.org/stable/3461834.

Ellis, Jay. No Place for Home: Spatial Constraint and Character Flight in the Novels of Cormac McCarthy. Routledge, 2006.

Folks, Jeffrey J., and James A. Perkins. Southern Writers at Century's End. The University Press of Kentucky, 2007.

Guillemin, George. "See the Child:' The Melancholy Subtext of Blood Meridian." Cormac McCarthy: New Directions. Ed. James D. Lilley. University of New Mexico Press, 2002, pp. 239-261.

Guinn, Matthew. After Southern Modernism: Fiction of the Contemporary South. 2010. 
Hall, Wade H., and Rick Wallach. Sacred Violence: A Reader's Companion to Cormac McCarthy. Texas Western, 2015.

Hanssen, Ken R. "'Men Are Made of the Dust of the Earth': Time, Space, Matter, and Meaning in Cormac McCarthy's Blood Meridian." The Cormac McCarthy Journal, vol. 15, no. 2, 2017, pp. 177-192.

Haslam, Gerald W. "Rediscovering The West." A Literary History of the American West. Ed. J. Golden Taylor. Texas Christian University Press, 1987, pp.1162-1178.

Hillier, R. M. Morality in Cormac McCarthy's Fiction: Souls at Hazard. Palgrave Macmillan, 2017.

Humphris, Luke. "What Do We Mean When We Say "Toxic Masculinity?" The Nib, June 27, 2018, //thenib.com/toxic-masculinity/.

James, Caryn. "Is Everybody Dead Around Here?" New York Times Book Review, 28 April 1985, www.nytimes.com/1985/04/28/books/is-everybody-dead-around- here.html.

Jarrett, Robert L. Cormac McCarthy. Twayne Publishers \& Prentice Hall International, 1997.

Jurgensen, John. "Hollywood's Favorite Cowboy." The Wall Street Journal, November 13, 2009, www.wsj.com/articles/SB1000142405274870457620457 4529703577274572.

Kittredge, William. Owning It All. Graywolf Press, 1987.

Kollin, Susan. "Genre and the Geographies of Violence: Cormac McCarthy and the Contemporary Western.” Contemporary Literature, vol. 42, no. 3, 2001, pp. 557-588. JSTOR, www.jstor.org/stable/120899.

Kupers, Terry A. "Toxic Masculinity as a Barrier to Mental Health Treatment in Prisons." Journal of Clinical Psychology, vol. 61, no 6, 2005, pp. 713-24. JSTOR, www.jstor.org/ stable/ 23415244.

Masters, Joshua J. "Witness to the Uttermost Edge of the World: Judge Holden's Textual Enterprise in Cormac McCarthy's Blood Meridian." Critique: Studies in Contemporary Fiction, vol. 40, no. 1, 1998, pp 25-37. JSTOR, www.jstor.org/stable/ 67325512.

Matz, Jesse. The Modern Novel: A Short Introduction. Blackwell, 2004.

McCarthy, Cormac. Blood Meridian: Or the Evening Redness in the West. Vintage, 1993.

McVeigh, Stephen. The American Western. Edinburgh University Press, 2017.

Meisenheimer, Donald K, Jr. "Machining the Man: From Neurasthenia to Psychasthenia in SF and the Genre Western." Science Fiction Studies, vol. 24, no. 3, 1997, pp. 441-58. JSTOR, www.jstor.org/stable/ 89005341 .

Messerschmidt, James. Hegemonic Masculinities and Camouflaged Politics. Paradigm Publishers, 2010.

Moos, Dan. "Lacking the Article Itself: Representation and History in Cormac McCarthy's Blood Meridian." The Cormac McCarthy Journal, vol. 2, no. 1, 2002, pp. 23-39. JSTOR, www.jstor.org/stable/42909344.

Phillips, Dana. History and the Ugly Facts of Cormac McCarthy's Blood Meridian." American Literature, vol. 68, no. 2, 1996, pp. 433-460. JSTOR, www.jstor.org/stable/2928305.

Pilkington, Tom. "Fate and Free Will on the American Frontier: Cormac McCarthy's Western Fiction." Western American Literature, vol. 27, no. 4, 1993, pp. 311-322. JSTOR, www.jstor.org/stable/43021039.

Scott, A.O. "The Sun Also Sets." The New York Review of Books, vol. 45, no. 14, 1998, pp. 26-29.

Shaw, Patrick W. “The Kid's Fate, the Judge's Guilt: Ramifications of Closure in Cormac McCarthy's Blood Meridian.'”The Southern Literary Journal, vol. 30, no. 1, 1997, pp. 102-119.JSTOR, www.jstor.org/stable/20078199.

Sepich, John Emil. "The Dance of History in Cormac McCarthy's Blood Meridian." The Southern Literary Journal, vol. 24, no. 1, 1991, pp. 16-31. 
Sexton, Jared Yates. The Man They Wanted Me to Be: Toxic Masculinity and a Crisis of Our Own Making. Counterpoint, 2019.

Slotkin, Richard. Gunfighter Nation: The Myth of the Frontier in Twentieth-Century America. Maxwell Macmillan International, 2002.

Shaviro, Steven. “The Very Life of the Darkness': A Reading of Blood Meridian.” Perspectives on Cormac McCarthy. Ed. Edwin T. Arnold and Dianne C. Luce. University Press of Mississippi, 1993, pp. 143-156.

Spurgeon, Sara. Exploding the Western: Myths of Empire on the Postmodern Frontier. Texas University Press, 2005.

Stephens, Jordan. "Toxic Masculinity is Everywhere. It is up to Us Men to Fix This." The Guardian, November 13, 2017, www.theguardian.com/ commentisfree/2017/oct/23/ toxic-masculinity-men-privilege-emotions-rizzle-kicks.

Sullivan, Nell. "Boys Will Be Boys and Girls Will Be Gone: The Circuit of Male Desire in Cormac McCarthy's The Border Trilogy." Southern Quarterly: A Journal of the Arts in the South, vol. 38, no. 3, 2000, pp.167-85. Project Muse, muse.jhu. edu/book/19638.

Roosevelt, Theodore. The Strenuous Life: Essays and Addresses. Century, 1901.

---. The Winning of the West: An Account of the Exploration and Settlement of Our Country from the Alleghanies to the Pacific. Gebbie and Co., 1903.

Tanner, Toni. The Reign of Wonder: Naivety and Reality in American Literature. Cambridge University Press, 2010.

Turner, Frederick Jackson. The Frontier in American History. Open Road Media, 2015.

Woodward, Richard B. "Cormac McCarthy's Venomous Fiction." The New York Times Magazine, 19 April 1992. 
